Artikel Penelitian

\title{
Penentuan Umur Simpan Menggunakan Metode Accelerated Shelf Life Test (ASLT) pada Bubuk Minuman Instan Stroberi Foam-Mat Drying
}

\author{
Shelf-life Determination using Accelerated Shelf Life Test (ASLT) Method for Foam-Mat Drying Instant \\ Drink Strawberry Powder
}

Sandi Darniadi1*, Ridwan Rachmat ${ }^{1}$, Prima Luna1, Winda Purwani2, Diny Agustini Sandrasari ${ }^{2}$

${ }_{1}^{1}$ Balai Besar Penelitian dan Pengembangan Pascapanen Pertanian, Badan Litbang Pertanian, Bogor

2Departemen Teknologi Pangan, Universitas Sahid, Jakarta

*Korespondensi dengan penulis (sandidarniadi@pertanian.go.id)

Artikel ini dikirim pada tanggal 9 April 2020 dan dinyatakan diterima tanggal 7 September 2020. Artikel ini juga dipublikasi secara online melalui https://ejournal2.undip.ac.id/index.php/jatp. Hak cipta dilindungi undang-undang. Dilarang diperbanyak untuk tujuan komersial.

Diproduksi oleh Indonesian Food Technologists $®(2020$

\begin{abstract}
Abstrak
Pengolahan buah stroberi dengan teknik pengeringan lazimnya dilakukan untuk tujuan memperpanjang umur simpan. Pada penelitian ini, bubuk minuman instan stroberi dibuat melalui proses foam-mat drying pada suhu $50{ }^{\circ} \mathrm{C}$ melalui penambahan putih telur $10 \%(\mathrm{~b} / \mathrm{b})$ sebagai agen pembuih, maltodekstrin $12 \%(\mathrm{~b} / \mathrm{b})$ dan Tween $800,1 \%$ (b/b) sebagai stabilizer buih pada sari buah stroberi. Penelitian ini bertujuan untuk menentukan umur simpan bubuk minuman stroberi instan dengan menggunakan metode ASLT (Accelerated Shelf Life Testing) berdasarkan model persamaan Arrhenius. Bubuk minuman instan stroberi disimpan pada suhu penyimpanan 35,45 , dan $55^{\circ} \mathrm{C}$ dengan waktu penyimpanan 15 hari. Kadar air, vitamin $\mathrm{C}$ dan skor mutu hedonik warna diamati tiap 3 hari. Hasil percobaan menunjukkan hubungan yang linier antara kenaikan kadar air, penurunan kadar vitamin $\mathrm{C}$, dan penurunan skor mutu hedonik warna terhadap waktu penyimpanan pada masing-masing suhu penyimpanan. Umur simpan produk bubuk minuman instan stroberi yang disimpan pada suhu penyimpanan 35,45 , dan $55^{\circ} \mathrm{C}$, menunjukkan hasil berdasarkan kadar air (11, 10, dan 9 hari), vitamin C (779, 773, dan 766 hari) dan mutu hedonik warna $(35,30$, dan 26 hari) secara berurutan. Kesimpulannya, umur simpan dapat ditentukan pada minuman instan stroberi dengan menghasilkan nilai yang spesifik tergantung pada parameter yang diteliti.
\end{abstract}

Kata kunci: Umur simpan, ASLT (Accelerated Shelf Life Testing), stroberi, foam-mat drying, bubuk minuman instan

\begin{abstract}
Processing of strawberry through drying method is designed to prolong its shelf life. This research used strawberry instant drink powder that was obtained using foam-mat drying method at $50^{\circ} \mathrm{C}$ with the addition of foaming agent, i.e. $10 \%(\mathrm{w} / \mathrm{w} /)$ of white egg, $12 \%(\mathrm{~W} / \mathrm{w})$ of maltodextrin and $0.1 \%(\mathrm{~W} / \mathrm{W})$ of Tween 80 as foam stabilizers, incorporated with strawberry juice. This study was aimed at determining the shelf life of strawberry instant drink powder using ASLT (Accelerated ShelfLife Testing) based on Arrhenius Model. The strawberry powder sample was stored at 35, 45, and $55^{\circ} \mathrm{C}$ for 15 days. Moisture content, vitamin $C$, and color hedonic score were measured per 3 days. The results showed that there was a linear relationship between the measurement parameters and storage time at those temperatures. The shelf life of strawberry powder at 35,45 , and $55^{\circ} \mathrm{C}$ were found as follows: according to moisture content (11.6, 10.7, and 9.9 days), vitamin C (779, 773, and 766 days), and color hedonic score (35, 30, and 26 days), respectively. As conclusion, strawberry instant drink powder was identified its shelf life and showed specific value as observed parameters.
\end{abstract}

Keywords: Shelf life, ASLT (Accelerated Shelf Life Testing), strawberry, foam-mat drying, instant drink powder

\section{Pendahuluan}

Buah stroberi (Fragaria $x$ ananassa Duch) merupakan salah satu produk hortikultura yang populer dan digemari masyarakat di Indonesia. Buah stroberi biasanya dipanen saat matang tua untuk mendapatkan kualitas maksimum seperti penampakan visual (kesegaran, warna, dan bentuk fisik), tekstur (juiciness and crispness), flavor dan nilai nutrisi (vitamin, mineral, serat pangan, dan fitonutrien) (Hernandezmunoz et al., 2008). Konsumsi buah stroberi dapat dilakukan dalam bentuk buah segar ataupun produk-produk olahannya. Produk hortikultura segar sangat mudah rusak (perishable) dan mengalami penurunan mutu sangat cepat, baik karena pengaruh masa simpan ataupun karena kondisi penyimpanannya (Nasution et al., 2013). Buah stroberi segar memiliki umur simpan maksimal dalam kondisi suhu rendah $0-1^{\circ} \mathrm{C}$ selama kurang lebih 4 hari. Lewat dari waktu dan kondisi tersebut dapat menyebabkan kualitas buah stroberi menjadi menurun sehingga mempengaruhi daya terima konsumen (Karina et al., 2012).

Salah satu upaya pengolahan agar buah tidak rusak adalah dengan melakukan diversifikasi produk sehingga dihasilkan produk dengan masa simpan yang lebih lama yaitu menjadi produk minuman bubuk instan (Kadam et al., 2012; Maria et al., 2019). Minuman bubuk 
instan stroberi dapat dilakukan menggunakan metode foam mat drying yang dilakukan dengan cara pengeringan sampel cair (sari buah, pulp) yang kemudian ditambahkan zat pembuih guna memerangkap udara pada sampel cair sehingga membantu meningkatkan luas permukaan pengeringan dan mengurangi waktu pengeringan (Karim and Wai, 1999). Putih telur biasanya digunakan sebagai zat pembuih (foaming agent) (Hardy and Jideani, 2017; Raharitsifa et al., 2006). Selain zat pembuih, foam stabilizer juga biasanya ditambahkan ke dalam sampel cair untuk menstabilkan buih. Zat hidrokoloid seperti maltodekstrin, gum xanthan, $\mathrm{CMC}$, dan gum guar adalah beberapa foam stabiliser yang digunakan pada proses foam-mat drying (Fredes et al., 2018; Kadam et al., 2012; Raharitsifa et al., 2006).

Metode foam mat drying merupakan metode pengeringan yang memberikan keuntungan diantaranya proses penghilangan air dapat berlangsung lebih cepat, memungkinkan penggunaan suhu yang lebih rendah, serta produk yang dihasilkan memiliki kualitas warna dan rasa yang baik serta lebih mudah dilarutkan dalam air (Hardy and Jideani, 2017; Seerangurayar et al., 2018). Diversifikasi buah stroberi melalui foam-mat drying belum pernah dilakukan pada studi lainnya, sehingga pengolahan stroberi menjadi bubuk minuman instan berpotensi menjadi metode pengawetan yang tepat dan bernilai ekonomis.

Untuk menjamin kualitas produk minuman bubuk stroberi instan yang dibuat, perlu diberikan suatu informasi yang menyatakan ketahanan produk selama penyimpanan yaitu umur simpan yang dapat ditentukan dengan melakukan pengamatan produk selama penyimpanan sampai terjadi perubahan yang tidak dapat diterima lagi oleh konsumen (Asiah et al. 2018). Lamanya waktu yang diperlukan seringkali menjadi masalah dalam penentuan umur simpan. Untuk mengatasi masalah waktu maka dapat digunakan metode pendugaan umur simpan yang memerlukan waktu lebih singkat, biaya lebih murah, mudah, dan memberikan hasil yang sesuai dengan prediksi kerusakan produk (Asiah et al., 2018). Metode pendugaan umur simpan yang dilakukan pada penelitian ini yaitu metode ASLT (Accelerated Shelf Life Testing). Penentuan umur simpan dengan metode ASLT ini telah banyak digunakan untuk produk nenas, papaya, cempedak, bawang merah, dan produk pastry (Arif, 2016; Hunaefi dan Ulfah, 2019; Setyadjit et al., 2017). Namun penentuan umur simpan produk bubuk minuman instan stroberi foam-mat drying belum pernah dilakukan oleh peneliti lain. Berdasarkan uraian tersebut, maka tujuan penelitian ini adalah untuk membuat produk minuman instan stroberi dengan metode foam-mat drying dan untuk menentukan umur simpan produk bubuk minuman instan stroberi foam-mat drying dengan menggunakan metode ASLT.

\section{Materi dan Metode \\ Materi}

Bahan utama percobaan adalah buah stroberi diperoleh dari pasar lokal di Jakarta. Buah stroberi yang digunakan dalam penelitian ini dipilih yang berwarna merah merata dan bebas dari kerusakan. Bahan-bahan lain yang digunakan yaitu maltodextrin, Tween 80, iodin, dan putih telur. Alat dan mesin yang digunakan dalam percobaan yaitu mixer (Philips, Indonesia), dry mill (Philips, Indonesia), cabinet dryer (Hadikreasi, Indonesia), oven incubator (Memmert, Germany), desikator, beaker glass, ayakan, dan loyang aluminium.

\section{Pembuatan sari buah stroberi}

Buah stroberi yang telah dipilih selanjutnya dicuci menggunakan air bersih dan pembuangan bagian batang dan daun yang masih menempel pada buah. Jumlah buah stroberi yang digunakan adalah sebanyak 150 gram untuk tiap percobaan. Selanjutnya, air ditambahkan pada buah stoberi sebanyak $700 \mathrm{ml} / \mathrm{kg}$ buah yang kemudian dicampur dengan menggunakan blender pada kecepatan $300 \mathrm{rpm}$ selama \pm 5 menit hingga nampak halus. Sari buah stroberi kemudian disaring menggunakan alat penyaring untuk memisahkan ampas hingga diperoleh sari buah stroberi (Darniadi et al., 2011)

\section{Proses Pengeringan dengan Foam-mat drying}

Proses foam-mat drying pada penelitian ini berdasarkan studi dari Kadam et al., (2012) dengan sedikit modifikasi. Sari buah stroberi ditambah dengan maltodekstrin $12 \%$ (b/b), Tween 80 0,1\% (b/b) sebagai foam stabilizer, dan putih telur $10 \%$ (b/b) sebagai foaming agent lalu dicampur dengan menggunakan mixer selama 10 menit dengan kecepatan sedang hingga memperoleh campuran yang berbuih dan stabil. Hasil pencampuran selanjutnya dituangkan ke dalam tray/loyang yang telah diberi alas plastik HDPE dengan ketebalan 2-3 cm lalu dikeringkan dalam cabinet dryer selama 4-5 jam pada suhu $50^{\circ} \mathrm{C}$. Lembaran kering sari buah stroberi yang telah kering dihancurkan menggunakan blender dry mill (1-2 menit) dengan ditambahkan sukrosa $30 \%$ (b/b) dan asam sitrat 0,05\% (b/b). Bubuk buah stroberi kemudian dihaluskan menggunakan alat pengayak 80 mesh untuk memperoleh bubuk stroberi dengan kehalusan yang seragam. Bubuk buah stroberi yang halus kemudian dikemas dalam kemasan metallized plastic dan ditutup menggunakan sealer untuk mencegah kerusakan pada minuman serbuk stroberi.

\section{Kadar air bubuk stroberi}

Pengukuran kadar berdasarkan metode AOAC (1995) dengan menggunakan 1-3 gram bubuk stroberi yang ditempatkan pada sebuah botol timbang yang dilengkapi dengan ditutup.

\section{Vitamin C bubuk stroberi}

Kadar vitamin C sebagai asam askorbat ditentukan dengan metode titrasi iodin (Arif, 2016) dengan menggunakan $25 \mathrm{ml}$ sampel yang dimasukkan ke dalam gelas piala dan ditambah 35 ml larutan kanjiasam sulfat. Larutan tersebut kemudian dititrasi dengan larutan iodin 0,1 M terstandarisasi. Asam askorbat 
$\mathrm{mg} / 100 \mathrm{ml}$ dihitung dengan membagi volume titran dengan volume sampel dan dikali 880,6 .

\section{Mutu hedonik warna}

Evaluasi sensori produk bubuk minuman instan stroberi foam-mat drying dilakukan melalui uji mutu hedonik (Faridah et al., 2013) dengan kriteria warna: merah (6); merah muda (5); merah keputihan (4); kekuningan (3); kuning kecoklatan (2); coklat kehitaman (1). Pengujian ini dilakukan oleh 25 orang panelis tidak terlatih.

\section{Penentuan umur simpan menggunakan metode ASLT}

Sebanyak 2 gram bubuk minuman instan stroberi yang dikemas menggunakan metalized plastic ditempatkan di dalam inkubator pada suhu 35,45 , dan $55{ }^{\circ} \mathrm{C}$. Sampling pengukuran parameter untuk kadar air, vitamin $\mathrm{C}$, dan mutu hedonik warna dilakukan tiap 3 hari sampai dengan 15 hari (Darniadi et al., 2012).

\section{Analisis data}

Proses pembuatan bubuk stroberi dilakukan secara triplicate. Nilai rata-rata dihitung dengan menyertakan standar deviasi pengukuran. Data karaktersitik fisik powder stroberi dihitung menggunakan Microsoft Excel 2013. Persamaan regresi linear digunakan untuk menentukan dasar umur simpan bubuk stroberi yang dibantu dengan software Minitab 19.

\section{Hasil dan Pembahasan \\ Pengamatan Kadar Air}

Kadar air awal bubuk stroberi foam-mat drying adalah $4,63 \pm 0,13 \%$, dimana nilai tersebut lebih rendah dibandingkan nilai kadar air produk bubuk minuman instan susu kedelai foam-mat drying yaitu 5,15\% (Purbasari, 2019). Seperti yang dilaporkan oleh Purbasari (2019), suhu selama foam-mat drying yang meningkat $\left(50-70{ }^{\circ} \mathrm{C}\right)$ menyebabkan kadar air bubuk susu kedelai menurun yaitu berkisar pada 3,31-5,15\%. $\mathrm{Hal}$ ini kemungkinan disebabkan oleh karakteristik susu kedelai yang mengandung lemak dan komposisi lainnya. Kadar air stroberi foam-mat drying pada penelitian ini dinilai kurang dari bubuk stroberi yang dikeringkan dengan microwave-vacuum drying $(10,98 \%)$ dan lebih tinggi daripada bubuk stroberi yang ditambahkan sukrosa yaitu 1,68 \% (Kowalska et al., 2018). Perbedaan nilai kadar air tersebut disebabkan oleh metode pengeringan dan perlakuan yang diberikan berbeda.

Figur 1 menunjukkan hasil analisis kadar air bubuk minuman instan stroberi foam-mat drying selama penyimpanan 15 hari. Kadar air bubuk stroberi mengalami kenaikan selama penyimpanan di semua suhu perlakuan. Penyimpanan hari ketiga menghasilkan kadar air 7,65, 7,84, dan 7,86 \%, masing-masing pada suhu 35,45 , dan $55^{\circ} \mathrm{C}$. Peningkatan kadar air terbesar pada bubuk stroberi terjadi pada penyimpanan hari ke12 sampai dengan hari ke-15, yaitu $3,5,7,59$, dan 8,33 $\%$, sehingga kadar air padah hari ke-15 mencapai 14,1 , 17,67 , dan $18,4 \%$ secara berurutan pada suhu 35,45 , dan $55^{\circ} \mathrm{C}$.

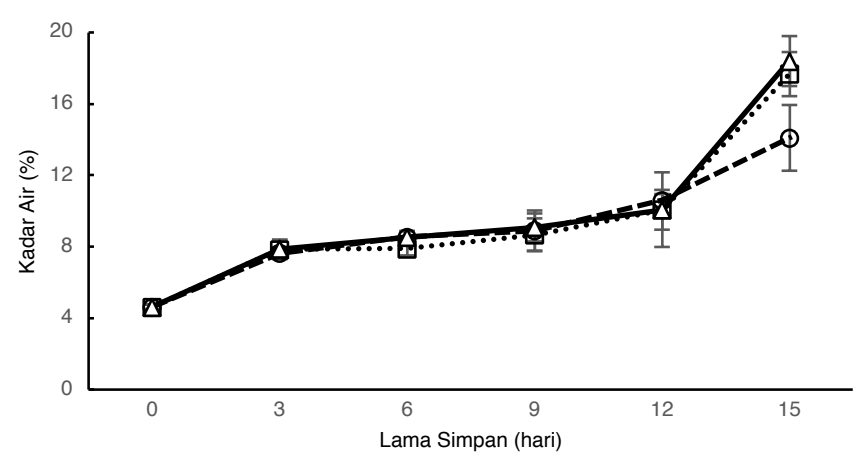

Figur 1 Kadar air (\%) bubuk minuman instan stroberi foam-mat drying selama penyimpanan pada suhu 35 (०), 45 (॰), dan 55 $(\Delta)^{\circ} \mathrm{C}$.

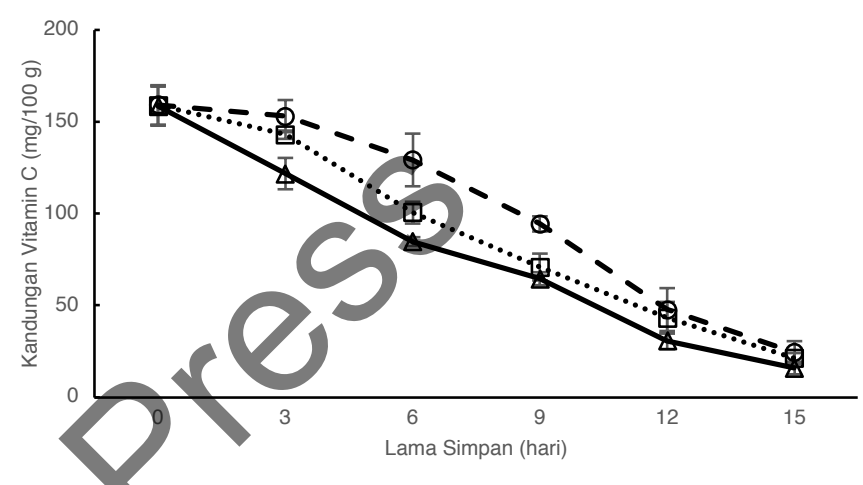

Figur 2 Kandungan vitamin $\mathrm{C}(\mathrm{mg} / 100 \mathrm{~g})$ bubuk minuman instan stroberi foam-mat drying selama penyimpanan pada suhu $35(\circ), 45(\square)$, dan $55(\Delta)^{\circ} \mathrm{C}$.

\section{Vitamin C}

Vitamin C sangat sensitif terhadap perubahan suhu, oksidasi, sinar, alkali dan enzim (Arif, 2016). Kondisi awal bubuk stroberi pada hari ke-0 penyimpanan yaitu $158,5 \mathrm{mg} / 100 \mathrm{~g}$. Kandungan vitamin C pada penelitian ini kurang dari nilai vitamin $\mathrm{C}$ bubuk stroberi vacuum-drying yaitu $490 \mathrm{mg} / 100 \mathrm{~g}$ (Kowalska et al., 2018). Figur 2 menunjukkan penurunan konsenterasi vitamin $C$ bubuk minuman instan stroberi foam-mat drying yang disimpan pada suhu akselerasi 35,45 , dan $55{ }^{\circ} \mathrm{C}$. Seiring bertambah waktu penyimpanan, konsenterasi vitamin $C$ pada produk semakin menurun. Penurunan vitamin $C$ bubuk stroberi terjadi sangat cepat pada suhu $55{ }^{\circ} \mathrm{C}$, sebaliknya pada suhu $35{ }^{\circ} \mathrm{C}$ laju penurunan nya relatif lambat kecuali setelah hari ke-9. Konsentrasi vitamin $\mathrm{C}$ pada akhir penyimpanan hari ke15 yaitu 24,$5 ; 21,4$ dan $16 \mathrm{mg} / 100 \mathrm{~g}$ pada suhu 35,45 , dan $55^{\circ} \mathrm{C}$ secara berurutan.

Kandungan vitamin $\mathrm{C}$ pada bubuk stroberi dengan pengeringan microwave-vacuum dapat bernilai $19-40 \%$, sedangkan pada bubuk stroberi freeze-drying berkisar 57-81 \% (Kowalska et al., 2018). Perbedaan kandungan vitamin C pada bubuk stroberi dapat disebabkan oleh varietas stroberi, metode pengeringan, dan pretreatment penelitian (Adak et al., 2017). Semakin tingginya kehilangan air, maka kandungan vitamin $C$ dapat menurun pada produk bubuk stroberi. Penelitian sebelumnya menunjukkan kehilangan vitamin $C$ dapat mencapai 70\% (Goula and Adamopoulos, 2010). 


\section{Skor Mutu Hedonik Warna}

Figur 3 menunjukkan penilaian panelis untuk mutu warna produk bubuk minuman instan stroberi foam-mat drying selama penyimpanan, dimana nilai 6 bermakna warna merah dan 1 bermakna warna cokelat kehitaman. Penilaian warna produk bubuk minuman instan stroberi foam-mat drying pada awal penyimpanan berada pada nilai 5 yaitu merah muda (Gambar 1). Pada penyimpanan hari ke-3, penilaian panelis untuk produk bubuk stroberi pada suhu 35 dan $45^{\circ} \mathrm{C}$ berkisar 4 (warna merah sedikit putih), sedangkan panelis memberikan nilai 3 (warna kekuningan) pada suhu akselerasi $55^{\circ} \mathrm{C}$. Di hari ke-15 penyimpanan, penilaian panelis untuk bubuk stroberi pada suhu 45 dan $55^{\circ} \mathrm{C}$ yaitu berkisar 1 (warna cokelat kehitaman), sedangkan nilai 2 (warna cokelat kehitaman) diberikan panelis untuk produk yang disimpan pada suhu $35^{\circ} \mathrm{C}$. Penurunan mutu warna selama penyimpanan pada suhu 35,45 , dan $55^{\circ} \mathrm{C}$ terjadi pada produk sirup buah pala. Skor mutu warna awal yaitu 10 menurun menjadi 4,67 pada skor kritis disebabkan panelis tidak menyukai warna sampel (Faridah et al, 2013).

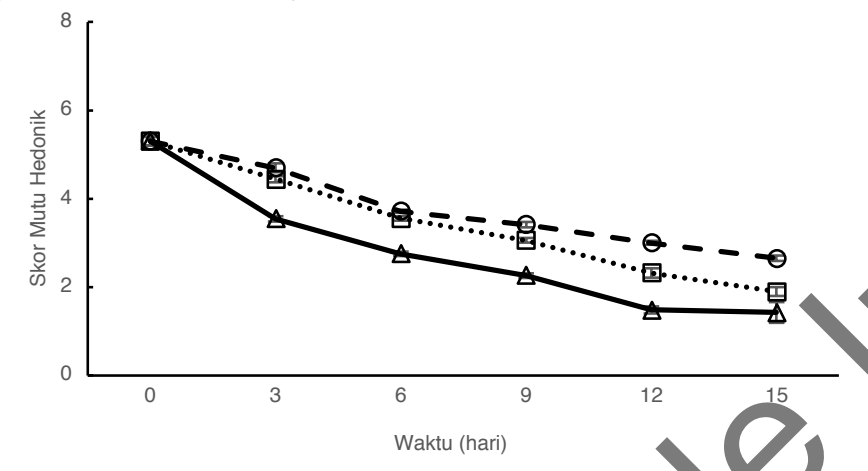

Figur 3 Kandungan vitamin $\mathrm{C}(\mathrm{mg} / 100 \mathrm{~g})$ bubuk minuman instan stroberi foam-mat drying selama penyimpanan pada suhu $35(\circ), 45(\square)$, dan $55(\Delta)^{\circ} \mathrm{C}$.

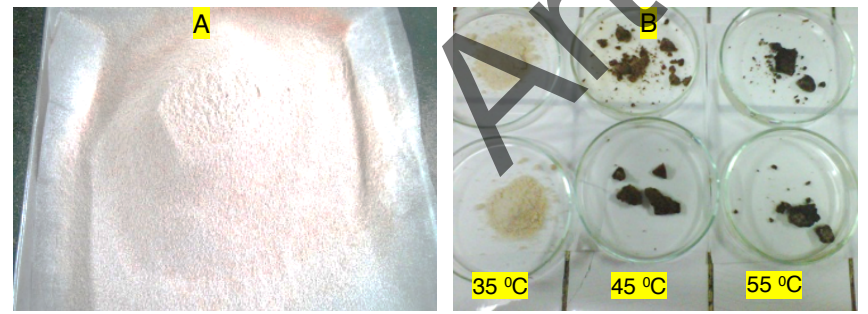

Gambar 1. Bubuk minuman instan stroberi foam-mat drying pada hari ke-0 (A) dan setelah penyimpanan hari ke-15 (B)

\section{Penentuan Umur Simpan dengan Metode ASLT}

Tahap awal dalam pendugaan umur simpan yaitu membuat grafik hubungan antara penurunan nilai parameter dan waktu penyimpanan pada kondisi suhu yang berbeda. Parameter yang diamati dalam eksperimen ini adalah kadar air, vitamin C, dan skor mutu hedonik warna. Persamaan regresi linear untuk 3 kondisi suhu akselerasi penyimpanan 35,45 , dan $55^{\circ} \mathrm{C}$ ditunjukkan pada Tabel 1. Untuk melanjutkan perhitungan umur simpan menggunakan Model Arrhenius, maka perlu dibandingkan nilai $\mathrm{R}^{2}$ (determinasi) tertinggi antara ordo 0 dan ordo 1.
Dari Tabel 1 terlihat bahwa nilai $\mathrm{R}^{2}$ untuk parameter kadar air ordo 1 lebih tinggi dibandingkan ordo 0 , yaitu 0,903; 0,863; dan 0,858 pada suhu 35,45 , dan $55{ }^{\circ} \mathrm{C}$ secara beruturan. Nilai $R^{2}$ parameter vitamin $C$ terlihat lebih tinggi pada ordo 0 dibandingkan ordo 1 , yaitu 0,959; 0,989; dan 0,984 untuk suhu penyimpanan 35, 45 , dan $55^{\circ} \mathrm{C}$ secara berurutan. Untuk parameter skor mutu hedonik warna, nilai $\mathrm{R}^{2}$ tertinggi diperoleh dari ordo 1 yaitu 0,$984 ; 0,995$; dan 0,966 pada suhu penyimpanan 35,45 , dan $55^{\circ} \mathrm{C}$ secara berurutan.

Setelah ditentukan ordo dengan nilai tertinggi dari untuk tiap parameter, nilai slope (b) dari persamaan linear (Tabel 1) diplot sebagai nilai $k$ (Tabel 2) ke Model Arrhenius In $k=\ln k_{0}-(E a / R)(1 / T)$. Nilai slope parameter kadar air yaitu 0,$0627 ; 0,0718$; dan 0,0733 untuk suhu penyimpanan 35,45 , dan $55{ }^{\circ} \mathrm{C}$ secara berurutan. Nilai slope parameter vitamin C yaitu $-9,7480$; -9,6780; dan 9,5790 untuk suhu penyimpanan 35,45 , dan $55^{\circ} \mathrm{C}$ secara berurutan. Nilai slope parameter skor mutu hedonik warna yaitu:- $-0,0466 ;-0,0688$; dan -0,0630 untuk suhu penyimpanan 35,45 , dan $55{ }^{\circ} \mathrm{C}$ secara berurutan. Pada Tabel 2 ditunjukkan nilai T (suhu oK) dan $1 / T$ yang digunakan untuk menghitung Model Arrhenius.

Persamaan Arrhenius untuk produk bubuk minuman instan stroberi foam-mat drying ditunjukkan pada Tabel 2. Pada parameter kadar air, persamaan Arrhenius yang dihasilkan yaitu In $\mathrm{k}=-0,174$ $793,7(1 / T)$, dimana nilai $\ln \mathrm{k}_{0}=-0.174,(\mathrm{Ea} / \mathrm{R})=-7,937$. Umur simpan dari persamaan tersebut dapat dihitung melalui input suhu penyimpanan $5{ }^{\circ} \mathrm{C}$ (atau $\left.278 \circ \mathrm{K}\right)$, didapatkan In $\mathrm{k}=-3,029036$ atau $\mathrm{k}=0,0048362$, artinya peningkatan kadar air sebesar 0,0048362 unit per hari. Oleh karena itu, total unit mutu sampai kadaluwarsa dapat dihitung dengan mengurangkan nilai mutu awal kadar air yaitu 4,77 dengan nilai batas kritis yaitu 10 (Faridah et al., 2013) sehingga dihasilkan 5,23 unit mutu. Perkiraan umur simpan ordo 1 berdasarkan parameter kadar air yaitu ts $=\left[\ln \left(\mathrm{N}_{0}-\mathrm{Nt}\right)\right] / \mathrm{k}$.

Persamaan Arrhenius parameter vitamin $\mathrm{C}$ (Tabel 2) yaitu In $\mathrm{k}=-1,991-88,15(1 / \mathrm{T})$ dimana nilai In $\mathrm{k}_{0}=-$ $1,991,(\mathrm{Ea} / \mathrm{R})=-88,15$. Umur simpan dari persamaan tersebut dapat dihitung melalui input suhu penyimpanan $5{ }^{\circ} \mathrm{C}$, didapatkan In $\mathrm{k}=-2,3080863$ atau $\mathrm{k}=0,099451$, artinya penurunan vitamin $C$ sebesar 0,099451 unit per hari. Oleh karena itu, total unit mutu sampai kadaluwarsa dapat dihitung dengan mengurangkan nilai mutu awal kadar air yaitu 160 dengan nilai batas kritis yaitu 80 (setengah nilai nilai vitamin $\mathrm{C}$ awal) sehingga menghasilkan 80 unit mutu (Arif, 2016). Perkiraan umur simpan ordo 0 berdasarkan parameter kadar air yaitu ts $=\mathrm{No}-\mathrm{Nt} / \mathrm{k}$.

Persamaan Arrhenius pada parameter skor mutu hedonik warna (Tabel 2) yaitu In $\mathrm{k}=2,052-1553(1 / \mathrm{T})$ dimana nilai $\ln \mathrm{k}_{0}=2,052,(\mathrm{Ea} / \mathrm{R})=-1553$. Umur simpan dari persamaan tersebut dapat diduga melalui input suhu penyimpanan $5{ }^{\circ} \mathrm{C}$, didapatkan $\ln \mathrm{k}=-3,534331$ atau $\mathrm{k}$ $=0,029718$, artinya penurunan skor mutu hedonik warna sebesar 0,029718 unit per hari. Oleh karena itu, total unit mutu sampai kadaluwarsa dapat dihitung dengan mengurangkan skor mutu awal mutu hedonik warna 
Tabel 1 Nilai slope, intersep, dan $\mathrm{R}^{2}$ Ordo 0 dan Ordo 1 reaksi kinetik kadar air, vitamin $\mathrm{C}$, dan skor mutu hedonik warna selama penyimpanan akselerasi

\begin{tabular}{|c|c|c|c|c|c|c|c|}
\hline \multirow[t]{2}{*}{ Parameter } & \multirow{2}{*}{$\begin{array}{c}\text { Suhu } \\
\text { akselerasi } \\
\left({ }^{\circ} \mathrm{C}\right)\end{array}$} & \multicolumn{3}{|c|}{ Ordo 0} & \multicolumn{3}{|c|}{ Ordo 1} \\
\hline & & Slope & Intersep & $\mathrm{R}^{2}$ & Slope & Intersep & $\mathrm{R}^{2}$ \\
\hline \multirow[t]{3}{*}{ Kadar air } & 35 & 0,5384 & 5,031 & 0,920 & 0,06273 & 1,680 & 0,903 \\
\hline & 45 & 0,6919 & 4,275 & 0,779 & 0,07181 & 1,628 & 0,863 \\
\hline & 55 & 0,7236 & 4,335 & 0,774 & 0,07332 & 1,644 & 0,858 \\
\hline \multirow[t]{3}{*}{ Vitamin C } & 35 & $-9,748$ & 174,5 & 0,959 & $-0,1252$ & 5,369 & 0,883 \\
\hline & 45 & $-9,678$ & 162,3 & 0,989 & $-0,1328$ & 5,286 & 0,947 \\
\hline & 55 & $-9,579$ & 151,3 & 0,984 & $-0,151$ & 5,246 & 0,956 \\
\hline \multirow{3}{*}{$\begin{array}{l}\text { Skor mutu } \\
\text { hedonik warna }\end{array}$} & 35 & $-0,1774$ & 5,128 & 0,959 & $-0,04655$ & 1,654 & 0,984 \\
\hline & 45 & $-0,2272$ & 5,133 & 0,986 & $-0,06882$ & 1,687 & 0,995 \\
\hline & 55 & $-0,2480$ & 4,654 & 0,904 & $-0,063$ & 0,5798 & 0,966 \\
\hline
\end{tabular}

Tabel 2. Model Arrhenius penurunan mutu kadar air, vitamin $\mathrm{C}$, dan skor mutu hedonik warna

\begin{tabular}{lcccccc}
\hline Parameter & $\mathrm{T}\left({ }^{\circ} \mathrm{C}\right)$ & $\mathrm{k}$ & $\mathrm{In} \mathrm{k}$ & $\mathrm{T}$ & $1 / \mathrm{T}$ & Persamaan Arrhenius \\
\hline Kadar Air & 35 & 0,0627 & $-2,7689$ & 308 & 0,00325 & In k $=-0,174-793,7(1 / \mathrm{T})$ \\
& 45 & 0,0718 & $-2,6337$ & 318 & 0,00314 & \\
Vitamin C & 55 & 0,0733 & $-2,6129$ & 328 & 0,00305 & \\
& 35 & 9,7480 & $-2,2771$ & 308 & 0,00325 & In $\mathrm{k}=-1,991-88,15(1 / \mathrm{T})$ \\
Skor mutu hedonik & 45 & 9,6780 & $-2,2699$ & 318 & 0,00314 & \\
warna & 55 & 9,5790 & $-2,2596$ & 328 & 0,00305 & \\
& 35 & 0,0466 & $-3,0672$ & 308 & 0,00325 & In k $=2,052-1553(1 / \mathrm{T})$ \\
& 45 & 0,0688 & $-2,6763$ & 318 & 0,00314 & \\
\hline
\end{tabular}

Tabel 3. Umur simpan bubuk stroberi berdasarkan parameter kadar air, vitamin C, dan skor mutu hedonik warna

\begin{tabular}{cccc}
\hline Suhu Pendugaan $\left({ }^{\circ} \mathrm{C}\right)$ & \multicolumn{3}{c}{ Umur Simpan (hari) } \\
\cline { 2 - 4 } & Kadar air (\%) & Vitamin C & Mutu hedonik warna \\
\hline-5 & 17,0 & 814,0 & 75,64 \\
5 & 15,3 & 804,4 & 61,41 \\
10 & 14,6 & 799,9 & 55,64 \\
15 & 13,9 & 795,6 & 50,58 \\
20 & 13,2 & 791,5 & 46,13 \\
25 & 12,6 & 787,5 & 42,21 \\
30 & 12,1 & 783,6 & 38,73 \\
35 & 11,6 & 779,9 & 35,64 \\
40 & 11,1 & 776,4 & 32,88 \\
45 & 10,7 & 773,0 & 30,41 \\
50 & 10,3 & 769,7 & 28,20 \\
55 & 9,9 & 766,5 & 26,21 \\
\hline
\end{tabular}

yaitu 6 dengan nilai batas kritis yaitu 1 sehingga menghasilkan 5 unit mutu. Perkiraan umur simpan ordo 1 berdasarkan parameter kadar air yaitu ts = [In(No$\mathrm{Nt})] / \mathrm{k}$.

Umur simpan produk bubuk minuman instan stroberi yang diperkirakan dengan menggunakan Model Arrhenius ditunjukkan pada Tabel 3. Berdasarkan parameter kadar air umur simpan produk bubuk stroberi pada suhu $25^{\circ} \mathrm{C}$ (ambient temperature) yaitu 12,6 hari. Peningkatan suhu penyimpanan menyebabkan penurunan umur simpan produk bubuk stroberi yaitu 11,$6 ; 10,7$; dan 9,9 hari masing-masing pada suhu 35, 45 , dan $55{ }^{\circ} \mathrm{C}$. Umur simpan produk bubuk stroberi berdasarkan penurunan vitamin $\mathrm{C}$ pada suhu $25^{\circ} \mathrm{C}$ yaitu 787,5 hari, sedangkan pada suhu 35,45 , dan $55^{\circ} \mathrm{C}$, umur simpannya masing-masing mencapai 779,9; 773; dan 766,5 hari. Umur simpan berdasarkan skor mutu hedonik warna pada suhu $25{ }^{\circ} \mathrm{C}$ yaitu 42,21 hari, sedangkan pada suhu 35,45 , dan $55^{\circ} \mathrm{C}$ masing-masing menjadi 35,64; 30,41; dan 26,21 hari.

Tabel 4. Perbandingan umur simpan bubuk minuman instan dengan produk sejenis

\begin{tabular}{clc}
\hline No* $^{*}$ & Produk minuman & $\begin{array}{c}\text { Umur simpan } \\
\text { (hari) }\end{array}$ \\
\hline 1 & Bubuk stroberi & 42 \\
2 & Bandrek instan & 341 \\
3 & Kopi instan & 732 \\
4 & Bubuk jahe merah & 629 \\
5 & Bubuk jahe instan & 268 \\
6 & Encapsulated ginger powder & 1479 \\
7 & Sari buah pala & 34 \\
8 & Sari akar alang-alang & 41 \\
\hline
\end{tabular}

${ }^{\star}$ No 2-8 dikutip dari (Faridah et al., 2013) 
Perbandingan Bubuk Stroberi dengan Produk Sejenis Vitamin $\mathrm{C}$ pada produk bubuk minuman instan stroberi dan buah lainnya menjadi sangat penting dalam penentuan umur simpan oleh karena adanya sifat yang mudah rusak akibat perubahan suhu selama proses dan penyimpanan (Derossi et al., 2010). Oleh karena itu, vitamin C dijadikan sebagai parameter kritis dalam perhitungan umur simpan bubuk minuman instan stroberi foam-mat drying. Beberapa produk minuman, baik minuman fungsional atau minuman sari buah, telah berhasil diteliti umur simpannya menggunakan metode ASLT (Faridah et al., 2013) sebagaimana ditunjukkan pada Tabel 3. Umur simpan bubuk stroberi foam-mat drying berdasarkan kandungan vitamin $\mathrm{C}$ pada suhu 25 ${ }^{\circ} \mathrm{C}$ yaitu 787 hari, relatif lebih lama dibandingkan produk sejenis, kecuali dibandingkan produk encapsulated ginger powder yang dapat mencapai 1.479 hari. Perbedaan umur simpan antara bubuk stroberi foam-mat drying dan produk sejenis dimungkinkan karena proses pengolahan, pengemasan, dan suhu penyimpanan yang berbeda.

\section{Kesimpulan}

Diversifikasi produk buah stroberi melalui metode foam-mat drying (pengeringan busa) dengan suhu $50{ }^{\circ} \mathrm{C}$ telah berhasil dilakukan pada penelitian ini. Produk akhir berupa bubuk minuman instan stroberi dibuat dengan bahan tambahan foaming agent (putih telur) dan foam stabilizer (maltodekstrin dan Tween 80). Penentuan umur simpan produk bubuk minuman instan stroberi dilakukan menggunakan metode Accelerated Shelf Life Testing (ASLT) dengan kondisi suhu penyimpanan 35, 45 , dan $55^{\circ} \mathrm{C}$. Hasil pendugaan umur simpan produk bubuk minuman instan stroberi pada suhu penyimpanan 35,45 , dan $55^{\circ} \mathrm{C}$ yaitu: berdasarkan kadar air (11, 10, 9 hari), vitamin $C(779,773,766$ hari), dan mutu hedonik warna $(35,30,26$ hari).

\section{Daftar Pustaka}

Adak, N., Heybeli, N., Ertekin, C.2017. Infrared drying of strawberry. Food Chemistry 219:109-116. DOI:10.1016/j.foodchem.2016.09.103.

AOAC. 1995. Assosiation of Oficial Analysis Chemis [AOAC]. Official Methods of Analysis of the AOAC. Gaithersburg, United States.

Arif, A. B. 2016. Metode accelerated shel life test (ASLT) dengan pendekatan Arrhenius dalam pendugaan umur simpan sari buah nanas, pepaya dan cempedak. Informatika Pertanian 25(2):189-198. DOI:10.21082/ip.v25n2.2016.p189-198.

Asiah, N., Cempaka, L., David, W. 2018. Metode Penentuan Umur Simpan. Dalam: Panduan Praktis Pendugaan Umur Simpan Produk Pangan. pp. 39-52. Penerbit Universitas Bakrie.

Budijanto, S., Boing, A., Dwi, Y. 2010. Penentuan umur simpan tortilla dengan metode akselerasi berdasarkan kadar air kritis serta pemodelan ketepatan sorpsi isotherminya. Jurnal Teknologi dan Industri Pangan (XXI) 2:165-170.

Darniadi, S., Adiandri, R.S., Hidayah, N. 2012. Pendugaan umur simpan produk pangan darurat snack bar berbasis tepung ubijalar dan kacangkacangan. Widyakarya Nasional Pangan dan Gizi $\mathrm{X}: 1823-1832$.

Darniadi, S., Sofyan, I., Arief, D.Z. 2011. Karakteristik fisiko-kimia dan organoleptik bubuk minuman instan jambu biji merah (Psidium guajava L.) yang dibuat dengan metode foam-mat drying. Widyariset 14(2):431-438.

Derossi, A., Pilli, T.D, Fiore, A.G. 2010. LWT - Food Science and Technology Vitamin C kinetic degradation of strawberry juice stored under nonisothermal conditions. LWT - Food Science and Technology 43(4):590-595. DOI:10.1016/j.Iwt. 2009.10.006.

Faridah, D.N., Yasni, S., Suswantinah, A., Aryani, G.W. 2013. Pendugaan umur simpan dengan metode accelerated shelf-life testing pada produk bandrek instan dan sirup buah pala (Myristica fragrans ). Jurnal IImu Pertanian Indonesia 18(3):144-153.

Fredes, C., Becerra, C., Parada, J., Robert, P. 2018. The microencapsulation of maqui (Aristotelia chilensis (Mol.) Stuntz) juice by spray-drying and freezedrying produces powders with similar anthocyanin stability and bioaccessibility. Molecules 23(5):1227. DOI:10.3390/molecules23051227.

Goula, A.M., Adamopoulos, K.G. 2010. Retention of ascorbic acid during drying of tomato halves and tomato pulp retention of ascorbic acid during drying of tomato halves and tomato pulp. Drying Technology 24:37-41. DOI:10.1080/07373930 500538709.

Hardy, Z., Jideani, V.A. 2017. Foam-mat drying technology: A review. Critical Reviews in Food Science and Nutrition 57(12):2560-2572. DOI:10.1080/10408398.2015.1020359.

Hernandezmunoz, P., Almenar, E., Valle, V., Velez, D., Gavara, R. 2008. Effect of chitosan coating combined with postharvest calcium treatment on strawberry (Fragariaxananassa) quality during refrigerated storage. Food Chemistry 110(2):428435. DOI:10.1016/j.foodchem.2008.02.020.

Hunaefi, D., Ulfah, F. 2019. Pendugaan umur simpan produk pastry dengan quantitative descriptive analysis (QDA) dan metode arrhenius. Jurnal Mutu Pangan 6(2):72-78. : :10.29244/jmpi. 2019.6.72.

Kadam, D.M., Wilson, R.A., Varinder, K., Chadha, S., Pratibha, K., Sumandeep, K., Patil, R.T., Rai, D.R. 2012. Physicochemical and microbial quality evaluation of foam-mat-dried pineapple powder. International Journal of Food Science and Technology 47(8):1654-1659. DOI:10.1111/ j.1365-2621.2012.03016.x.

Karim, A.A., Wai, C.C. 1999. Foam-mat drying of starfruit (Averrhoa carambola L.) puree. Stability and air drying characteristics. Food Chemistry 64(3):337343. DOI:10.1016/s0308-8146(98)00119-8.

Karina, A.R., Trisnowati, S., Indradewa, D. 2012. Pengaruh macam dan kadar kitosan terhadap umur simpan dan mutu buah stroberi (Fragaria $x$ 
ananassa Duch.). Vegetalika 1(3). DOI:10.22146/veg.1366.

Kowalska, J., Kowalska, H., Marzec, A., Brzezin, T., Samborska, K., Lenart, A. 2018. Dried strawberries as a high nutritional value fruit snack. Food Science Biotechnology 27:799-807. DOI:10.1007/s10068-018-0304-6.

Maria, I., Tavares, D.C., Bonatto, M., Castilhos, M. De, Aparecida, M., Mota, A., Teodoro, R., Souza, D., Gómez-alonso, S., Gomes, E., Da-silva, R., Hermosín-gutiérrez, I., Lago-vanzela, E.S. 2019. BRS Violeta ( BRS Rúbea $\times$ IAC 1398-21) grape juice powder produced by foam mat drying. Part I: Effect of drying temperature on phenolic compounds and antioxidant activity. Food Chemistry 298: 124971. DOI:10.1016/j.foodchem. 2019.124971

Nasution, R.P., Trisnowati, S., Putra, E.T.S. 2013. Pengaruh lama penyinaran ulraviolet-c dan cara pengemasan terhadap mutu buah stroberi (Fragaria $x$ ananassa Duchesne) selama penyimpanan. Vegetalika 2(2):87-99. DOI:10.22146/veg.2418.

Purbasari, D. 2019. Aplikasi metode foam-mat Drying dalam pembuatan bubuk susu kedelai instan. Jurnal Agoteknologi 13(01):52-61. DOI:10.19184/ j-agt.v13i01.9253.

Raharitsifa, N., Genovese, D.B., Ratti, C. 2006. Characterization of apple juice foams for foammat drying prepared with egg white protein and methylcellulose. Journal of Food Engineering and Physical Properties 71(3):E142-E151. DOI:10.1111/j.1365-2621.2006.tb15627.x.

Seerangurayar, T., Manickavasagan, A., Al-Ismaili, A.M., Al-Mulla, Y.A. 2018. Effect of carrier agents on physicochemical properties of foam-mat freezedried date powder. Drying Technology 36(11)1292-1303. DOI:10.1080/07373937.2017.1400557

Setyadjit, Sukasih, E., Arif, A. 2017. Prediction of storage life of shallot powder by using acceleration method. International Journal of Agriculture System 5(2):140-153. DOI:10.20956/ijas.v5i2. 1236. 